\title{
APLIKASI ON FARM RESEARCH TEKNOLOGI MIKRONUTRISI UNTUK MENINGKATKAN PENDAPATAN RUMAH TANGGA ANGGOTA KELOMPOK TANI
}

\section{MICRONUTRITIONAL TECHNOLOGY ON FARM RESEARCH APPLICATION TO IMPROVE FARMER'S HOUSEHOLD INCOME}

\author{
Oleh: \\ Heri Dwi Putranto ${ }^{1)}$, Yossie Yumiati ${ }^{2)}$, Novitri Kurniati ${ }^{3)}$ \\ ${ }^{1)}$ Jurusan Peternakan Fakultas Pertanian Universitas Bengkulu \\ ${ }^{2)}$ Prodi Agribisnis Fakultas Pertanian Universitas Dehasen Bengkulu \\ ${ }^{3)}$ Jurusan Agribisnis Fakultas Pertanian Universitas Muhammadiyah Bengkulu \\ Email: heri_dp@unib.ac.id
}

\begin{abstract}
Cattle has been widely captived as a livestock in Indonesia. Unfortunately, eventhough the Ministry of Agriculture Republic of Indonesia launched a national program called Program Swasembada Daging Sapi dan Kerbau since 2014, the program result did not reach as high as targeted. Previous IbM program cooperated with Warga Rukun II Farmers Group located at Lokasi Baru Village, Air Periukan District, Seluma Regency, Bengkulu Province. Based on result of on farm research applied in site, the treatment of micronutritional supplemen (3\%) on cattles was feasible to be applied and it gave farmers a household income improvement.
\end{abstract}

Keywords: farmers group, household income, micronutritional technology

\section{PENDAHULUAN}

Masalah utama peternak dan anggota kelompok tani Warga Rukun II di Desa Air Lokasi Baru Kecamatan Air Periukan yaitu rendahnya angka kesuksesan reproduksi sapi potong berdasarkan rendahnya angka kelahiran (31 pedet per 80 ekor betina). Salah satu solusi yang sederhana, ekonomis dan ramah lingkungan yang ditawarkan adalah pemanfaatan tanaman tradisional. Apalagi ketersediaan tanaman katuk cukup banyak dijumpai di lahan kebun dan sawah petani di lokasi kegiatan IbM dan belumnya dimanfaatkan.

Mengingat ketersediaan tanaman katuk yang cukup banyak dan belum termanfaatkan secara maksimal oleh masyarakat selain untuk sayur dalam kehidupan sehari-hari, maka aplikasi hasil penelitian berupa utilisasi mikronutrisi suplemen tradisional (tanaman katuk) pada ternak ruminansia potong untuk memperbaiki status reproduksi, meningkatkan populasi ternak potong sekaligus mendukung program ketahanan pangan di Provinsi Bengkulu selayaknya dapat diterapkan.

Sebagai solusi permasalahan mitra, kegiatan IbM ini akan menerapkan teknologi utilisasi mikronutrisi suplemen tradisional yang merupakan hasil dari kegiatan penelitian 
Hibah Bersaing tahun 2013, 2014 dan 2015. Agar solusi yang telah disepakati lebih mudah diterima dan diserap oleh petani/peternak dan anggota kelompok tani maka tim pengusul mendesain suatu teknologi utilisasi mikronutrisi suplemen tradisional berupa tanaman katuk (Sauropus androgynus L Merr) dalam bentuk bahan segar ataupun ekstrak dengan teknik yang sederhana, bernilai ekonomis karena murah harganya dan mudah ditemukan, berbasis pada potensi lokal, serta sangat ramah lingkungan (eco friendly).

Penggunaan tanaman katuk (Sauropus androgynus (L.) Merr) sebagai suplemen pakan atau feed additive telah diteliti dalam kurun waktu 2 dasawarsa terakhir. Dalam bidang reproduksi, dinyatakan bahwa asam benzoat yang terkandung dalam tanaman katuk, akan dikonversikan menjadi estradiol benzoat di dalam tubuh. Estradiol benzoat berperan untuk meningkatkan fungsi reproduksi dan merangsang pertumbuhan folikel.

\section{METODE PENGABDIAN}

Melalui kegiatan Pengabdian Pada Masyarakat (PPM) program Ipteks Bagi Masyarakat (IbM) tahun 2015 yang memprioritaskan keaktifan dan pemberdayaan masyarakat dengan melibatkan peternak dan anggota kelompok tani, tim pelaksana melakukan beberapa upaya untuk mengatasi permasalahan keterbatasan pengetahuan masyarakat tentang teknologi mikronutrisi suplemen tradisional dengan beberapa tahapan kegiatan yaitu: (1) Tahapan Kegiatan Penyuluhan, (2) Tahapan Kegiatan Praktik, dan (3) Tahapan Kegiatan Demplot Percobaan. Adapun tahapan-tahapan kegiatan tersebut dapat dilihat dalam Tabel 1.

Tabel 1. Tahapan Kegiatan PPM Program IbM tahun 2014

\begin{tabular}{|c|c|c|c|}
\hline Tahap & $\begin{array}{c}\text { Jenis } \\
\text { Kegiatan }\end{array}$ & Lokasi & Topik \\
\hline 1 & Penyuluhan & $\begin{array}{l}\text { Rumah Ketua } \\
\text { Kelompok Tani } \\
\text { Warga Rukun II }\end{array}$ & $\begin{array}{l}\text { a. Pengenalan tanaman katuk (jenis, ciri- } \\
\text { ciri dan kegunaan). } \\
\text { b. Pengenalan tentang kesehatan ternak, } \\
\text { kesehatan reproduksi dan manajemen } \\
\text { pemeliharan intensif ternak potong. }\end{array}$ \\
\hline 2 & Praktik & $\begin{array}{l}\text { Rumah Ketua } \\
\text { Kelompok Tani } \\
\text { Warga Rukun II } \\
\text { dan Kandang } \\
\text { Ternak Anggota } \\
\text { Kelompok Tani }\end{array}$ & $\begin{array}{l}\text { Praktik proses persiapan tanaman katuk } \\
\text { sebagai feed additif antara lain: } \\
\text { a. Proses penjemuran } \\
\text { b. Proses pembuatan tepung ( } \text { oowder) } \\
\text { Proses pembuatan ekstrak }\end{array}$ \\
\hline 3 & $\begin{array}{l}\text { Demplot } \\
\text { Percobaan }\end{array}$ & $\begin{array}{l}\text { Kandang Ternak } \\
\text { Anggota Kelompok } \\
\text { Tani }\end{array}$ & $\begin{array}{l}\text { Aplikasi mikronutrisi tanaman katuk } \\
\text { dalam bentuk segar sebagai suplemen } \\
\text { untuk sapi potong }\end{array}$ \\
\hline 4 & $\begin{array}{l}\text { Monitoring } \\
\text { dan Evaluasi }\end{array}$ & Laboratorium & $\begin{array}{l}\text { Uji Konsentrasi Hormon Seksual dan } \\
\text { Analisis Agribisnis Suplementasi }\end{array}$ \\
\hline
\end{tabular}

Kegiatan IbM ini telah diadakan sejak bulan April hingga Oktober 2015 bertempat di Desa Lokasi Baru Kecamatan Air Periukan Kabupaten Seluma Provinsi Bengkulu. 
Mitra kegiatan adalah Kelompok Tani Warga Rukun II yang dipimpin oleh Bapak M. Said. Selama pelaksanaan kegiatan, tim pelaksana dibantu oleh beberapa mahasiswa Jurusan Peternakan Fakultas Pertanian Universitas Bengkulu terutama pada saat pelaksanaan demplot percobaan. Adapun tugas mahasiswa tersebut meliputi:

a. Mendampingi peternak anggota Kelompok Tani Rukun Warga II dalam pelaksanaan demplot percobaan.

b. Mengawasi jalannya demplot percobaan di kandang.

c. Mengumpulkan data agribisnis dan koleksi sampel darah.

\section{HASIL DAN PEMBAHASAN}

Dalam pelaksanaan demplot percobaan, dilakukan persiapan antara lain identifikasi lokasi kandang ternak dengan kriteria:

a. Peternak telah terbiasa dalam memelihara ternak sapi.

b. Tersedia sarana dan prasarana produksi.

c. Peternak bersedia untuk mengikuti petunjuk dan bimbingan teknis pelaksanaan kegiatan.

Pada Tabel 2 dapat dilihat bahan-bahan yang dipergunakan. Pakan berupa hijauan (rumput lapangan dan hijauan segar) diberikan ad libitum serta suplemen katuk diberikan dalam 3 taraf yaitu:

$\mathrm{Ka} 1=$ non-suplementasi

$\mathrm{Ka} 2=$ suplementasi katuk $3 \%$ dari berat hidup

$\mathrm{Ka} 3=$ suplementasi katuk $6 \%$ dari berat hidup

Tabel 2. Bahan-bahan yang dipergunakan dalam penelitian

\begin{tabular}{|c|c|c|c|}
\hline \multirow{2}{*}{ Uraian } & \multicolumn{3}{|c|}{ Perlakuan } \\
\hline & Ka1 & Ka2 & Ka3 \\
\hline a. Populasi sapi & 3 & 3 & 3 \\
\hline $\begin{array}{l}\text { b. Umur (bulan) } \\
\text { Ransum }\end{array}$ & 2 & 2 & 2 \\
\hline $\begin{array}{l}\text { Hijauan (rumput } \\
\text { lapangan dan daun) per } \\
\text { hari per ekor }\end{array}$ & $\begin{array}{c}5680,46 \mathrm{gr} \\
(100 \%)\end{array}$ & $\begin{array}{c}6753,27 \mathrm{gr} \\
(97 \%)\end{array}$ & 5466,50 gr $(94 \%)$ \\
\hline $\begin{array}{l}\text { Tanaman Katuk (yang } \\
\text { dikonsumsi) per hari per } \\
\text { ekor }\end{array}$ & $\begin{array}{l}0 \mathrm{gr} \\
(0 \%)\end{array}$ & $\begin{array}{c}4020,2 \mathrm{gr} \\
(3 \%)\end{array}$ & $\begin{array}{l}9055,6 \mathrm{gr} \\
(6 \%)\end{array}$ \\
\hline c. Kesehatan Ternak & sehat & sehat & sehat \\
\hline
\end{tabular}

1. Laju Pertumbuhan dan Konsumsi Ransum

Laju pertumbuhan diamati melalui pertambahan berat badan (PBB) yang diukur dengan cara menimbang sapi pada awal dan akhir masa pengamatan. Untuk melihat laju 
pertumbuhan berupa kenaikan PBB pada setiap level suplementasi dapat dilihat pada Tabel 3.

Hasil konsumsi hijauan (rumput lapangan dan daun-daunan) pada setiap perlakuan (Tabel 2) dikategorikan hampir setara. Secara umum pakan hijauan paling banyak dikonsumsi oleh sapi perlakuan Ka2 (6753,27 gr) dibanding Ka3 maupun Ka1. Sedangkan untuk konsumsi katuk, terbanyak dikonsumsi oleh sapi perlakuan Ka3 (9055,6 gr) dibanding A2.

Tabel 3. Rataan laju pertumbuhan sapi selama 60 hari perlakuan

\begin{tabular}{cccc}
\hline & \multicolumn{3}{c}{ PERLAKUAN SUPLEMENTASI } \\
\cline { 2 - 4 } Minggu ke- & Ka1 & Ka2 & Ka3 \\
\cline { 2 - 4 } & \multicolumn{3}{c}{------ gr/ekor/minggu - ------- } \\
\hline 1 & 240,30 & 270,67 & 235,00 \\
2 & 335,00 & 273,33 & 236,67 \\
3 & 316,67 & 430,00 & 403,33 \\
5 & 400,00 & 463,33 & 416,67 \\
5 & 493,33 & 480,00 & 486,67 \\
\hline Rataan & 357.06 & 383,47 & 355,67 \\
\hline
\end{tabular}

Keterangan: Ka1 = perlakuan hijauan ad libitum dan non-suplementasi, Ka2 = perlakuan hijauan ad libitum dan suplementasi katuk 3\% dari berat hidup, Ka3 = perlakuan hijauan ad libitum dan suplementasi katuk 6\% dari berat hidup.

Sebagai pembanding pada ternak unggas, suplementasi katuk sebesar 3\% dalam pakan dapat meningkatkan pertumbuhan dan efisiensi penggunaan pakan (Santoso dan Sartini, 2001). Selanjutnya Santoso et al. (2005) melaporkan bahwa pemberian ekstrak katuk pada ayam petelur akan dapat meningkatkan PBB. Menurut Azis dan Muktiningsih (2006), katuk merupakan tanaman sayuran yang mengandung zat gizi tinggi, mengandung kalori 59 kal, 6,4 g protein, 1 gr lemak, 9,9 gr hidrat arang, 1,5 gr serat, 1,7 gr abu, $233 \mathrm{mg}$ kalsium, $98 \mathrm{~g}$ phospor dan lain sebagainya. Termasuk beberapa senyawa metabolit sekunder yang sangat penting dalam metabolisme lemak dan protein dalam tubuh (Putranto et al., 2014).

\section{Analisis Agribisnis}

Untuk melihat hasil analisis agribisnis utilisasi mikronutrisi katuk pada 3 level suplementasi selama periode demplot percobaan dapat dilihat pada Tabel 4 berikut. Secara perhitungan penerimaan (PBB dan harga jual daging 60\% dari total karkas), perlakuan Ka1 mendapatkan nilai yang paling tinggi.

Nilai rasio R/C dalam penelitian ini dapat memperlihatkan kinerja ekonomi (Jakfar dan Irwan, 2011) perlakuan utilisasi mikronutrisi katuk. Nilai R/C tertinggi terdapat pada perlakuan utilisasi mikronutrisi non-suplemen (1,9) dibandingkan dengan perlakuan suplemen (1,05 dan 0,8). Menurut Soekartawi (1991), jika nilai R/C > 1 maka usaha dapat 
dikategorikan layak untuk dilanjutkan. Semakin tinggi nilai R/C maka usaha tersebut semakin mendatangkan keuntungan.

Perlakuan suplementasi katuk pada taraf 3\% dari berat hidup sapi telah menghasilkan angka $\mathrm{R} / \mathrm{C}$ di atas 1 , walaupun nilai tersebut lebih kecil dibanding perlakuan non-suplementasi. Tetapi apabila dibandingkan dengan pendapat Soekartawi (1991) maka perlakuan suplementasi taraf $3 \%$ sudah layak untuk dikembangkan.

Tabel 4. Analisis Agribisnis Utilisasi Mikronutrisi Katuk pada Sapi Betina selama Demplot

\begin{tabular}{|c|c|c|c|c|}
\hline \multirow{2}{*}{ No } & \multirow{2}{*}{ URAIAN } & \multicolumn{3}{|c|}{ PERLAKUAN } \\
\hline & & Ka1 & Ka2 & Ka3 \\
\hline \multirow[t]{9}{*}{1} & Biaya Produksi & & & \\
\hline & Biaya Variabel & & & \\
\hline & a. Bibit Sapi & 3 & 3 & 3 \\
\hline & b. Ransum & & & \\
\hline & - Rumput & $198,816 \mathrm{~kg} \mathrm{x}$ & $236,364 \mathrm{~kg} \mathrm{x}$ & $191,327 \mathrm{~kg} \mathrm{x}$ \\
\hline & lapangan & $\operatorname{Rp} 5.000 \times 3=$ & $\operatorname{Rp} 5.000 \times 3=$ & $\operatorname{Rp} 5.000 \times 3=$ \\
\hline & V & $\operatorname{Rp} 2.982 .240,-$ & Rp 3.545.460,- & Rp 2.869.905,- \\
\hline & - Katuk & 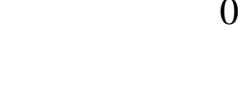 & $\begin{array}{r}140,707 \mathrm{~kg} \times \\
\operatorname{Rp} 2500 \times 3=\end{array}$ & $\begin{array}{r}316,946 \mathrm{~kg} \times \\
\mathrm{Rp} 2500 \times 3=\end{array}$ \\
\hline & c. Obat-obatan & 75.000 & $\begin{array}{r}\text { Rp 1.055.302,-- } \\
75.000\end{array}$ & $\begin{array}{r}\text { Rp 2.377.095,- } \\
75.000\end{array}$ \\
\hline
\end{tabular}

Biaya Tetap

a. Penyusutan

- Kandang

220.000

85.000

75.000

- Peralatan

50.000

50.000

50.000

JUMLAH (Rp)

3.327.240,-

4.819.762,-

5.447.000,-

2 Penerimaan

(PBB dan daging)

$$
\begin{array}{rr}
150 \times \operatorname{Rp~} 110.000 & 150 \times \operatorname{Rp} 110.000 \\
\times 3 \times 0,6= & \times 3 \times 0,6= \\
\operatorname{Rp} 9.900 .000,- & \operatorname{Rp} 9.900 .000,-
\end{array}
$$
$150 \times \operatorname{Rp} 110.000$ $\mathrm{x} 3 \times 0,6=$
Rp 9.900.000,-

$150 \times \operatorname{Rp} 110.000$ $\times 3 \times 0,6=$

Rp 9.900.000,-

\begin{tabular}{rlrrr}
\hline 3 & Keuntungan $(\mathrm{Rp})$ & $\mathbf{6 . 5 7 2 . 7 6 0 , -}$ & $\mathbf{5 . 0 8 0 . 2 3 8 , -}$ & $\mathbf{4 . 4 5 3 . 0 0 0 , -}$ \\
\hline 4 & R/C & $\mathbf{1 , 9}$ & $\mathbf{1 , 0 5}$ & $\mathbf{0 , 8}$ \\
\hline
\end{tabular}

Sumber: data diolah tahun 2015 


\section{KESIMPULAN}

Dapat disimpulkan bahwa berdasarkan hasil analisis agribisnis perlakuan utilisasi mikronutrisi suplementasi katuk (Ka2) layak untuk dikembangkan dan dapat mendatangkan keuntungan bagi peternak.

\section{UCAPAN TERIMA KASIH}

Tim pelaksana PPM IbM tahun 2015 mengucapkan terima kasih kepada Kementerian Riset, Teknologi dan Pendidikan Tinggi Republik Indonesia yang telah mendanai kegiatan ini melalui dana pengabdian Ipteks Bagi Masyarakat (IbM) dengan nomor kontrak 381/UN30.15/PM/2015 tanggal 10 Maret 2015. Ucapan terima kasih juga ditujukan kepada LPPM UNIB dan mitra kegiatan.

\section{DAFTAR PUSTAKA}

Azis, S. dan S.R. Muktiningsih, 2006, Studi Manfaat Daun Katuk (Sauropus androgynus), Cermin Dunia Kedokteran 151 (50): 48-50.

Jakfar, M. dan Irwan, 2011, Analisis Ekonomi Penggemukan Kambing Kacang Berbasis Sumber Daya Local, Jurnal Sains Riset (1): 1-7.

Putranto, H.D., Nurmeliasari, Ginting, S.M., Yumiati, Y., 2014, Skrining Senyawa Metabolit Steroid Sebagai Hormon Reproduksi Ternak pada Tanaman Katuk dan Jantung Pisang, Jurnal Peternakan Indonesia, Vol. 16 (1): 20-25.

Santoso, U., Sartini, 2001, Reduction of Fat Accumulation in Broiler Chickens by Sauropus Androgynus (Katuk) Leaf Meal Supplementation, Asian Australian Journal of Animal Science 14: 346-350.

Santoso, U., Setianto, J., Suteky, T., 2005, Effect of Sauropus Androgynus Extract on Egg Production and Lipid Metabolism in Layers, Asian Australian Journal of Animal Science 18 (3): 364-369.

Soekartawi, 1991, Dasar-Dasar Penyusunan Evaluasi Proyek, Pustaka Sinar Harapan, Jakarta. 